\title{
GO: On the Geographies of Gunnar Olsson
}

\author{
P. Romanillos \\ Geography, College of Life and Environmental Sciences, University of Exeter, Exeter, Devon EX4, UK \\ Correspondence to: P. Romanillos (j.1.romanillos@exeter.ac.uk)
}

\begin{abstract}
Abrahamsson, C. and Gren, M. (Eds.): GO: On the Geographies of Gunnar Olsson, Ashgate Publishing, Farnham, xiv +398 pp. EUR 106 Euro/GBP 77 hardback, ISBN-978-14094-1237-3, 2012.

Everything suggests, therefore, that geographers have a need for a geometry which topologists have suggested but not yet seem to have invented - a geometry with holes in.
\end{abstract}

Olsson, "Geography, 1984" (Bristol Seminar, 1967 cited in Abrahamsson \& Gren, 2012:46)

I want to start this review with the following question: why is it that so many introductory texts on the philosophical history of geography, on the theoretical multiplicity of spatial thought or even on key, "individual", thinkers on space and place have a tendency to pass over the work of Gunnar Olsson? As if responding to this surprising and saddening omission, GO: On the Geographies of Gunnar Olsson provides a kind of portable archive, reminding readers of Olsson's interventions - at turns analytic, creative, playful and rigorous - in the landscapes of geographical thought. Just under half of the chapters are texts, seminars or journal articles by Olsson himself, composing a selective anthology of his writings across 5 decades of scholarship. Early essays and seminars on the epistemological assumptions of spatial science and the ideological dimensions of spatial planning demonstrate the significance of Olsson's work for a critical reckoning with the quantitative revolution. Then there are the journal essays, reproduced, like the early essays and seminars, as facsimile copies of original publication formats. This stylistic device adds to the archival impression of the book but was perhaps chosen for Hegelian methodological reasons long articulated by Olsson: namely, that the instruments of access - words or lines, their modes and forms of communication - shape what appears or what comes to sense.

Across a number of these original facsimiles, such as "-I-" (1982), "The Social Space of Silence" (1987) and "Chiasm of Thought and Action" (1993), Olsson unfolds the episte- mological and ontological challenges posed by the semiological and linguistic philosophies that would play such an important part in the "cultural turn" of the late 1980s and 1990s. Finally, there are Olsson's innovative and exemplary critiques of the norms, assumptions and possibilities of cartographic reason. One of the refrains that Olsson chants across a number of these texts concerns the richness and invisibility of relations: the complexity of social relations that exceed any individuated thing, object or being. From my own reading of Olsson, I've always considered this privileging of relations to be a properly geographical assault on cartography, in which the cartographic device, the map, is made to appear as the least of geographical entities because of its inability to express relations (not to mention its normalization of the point, or location, as a despotic signifier of stable things or spatial forms). In this context, the map acts as a plane upon which relations are sacrificed to the illusory consistency of things.

However, the book also includes two other kinds of chapters that are integrated alongside Olsson's own essays and that perform different kinds of work. First, there are texts that deploy performative engagements with Olsson's writings. In particular, chapters by Tom Mels, Jette Hansen-Møller, Christian Abrahamsson, Alessandra Bonazzi and Marcus Doel present critical elaborations that usefully interpolate the selection of Olsson's own texts into contexts as varied as the legacies of post-structuralist semiology, diagrammatizations of power and Kantian thought or that draw upon Olsson's critique of cartographical reason in thinking through the figure of the globe or sphere. These creative engagements with Olsson's work help to situate, explicate and connect Olsson's own writings with multiple contemporary spatial-theoretic concerns. They also help simply to communicate the infectious intellectual energy opened by encounters with Olsson; tracing what is made possible and opened by a thinking that questions assumed or unacknowledged foundations - such as the value of systematic thought, the representational status of the map, scientific reasoning or the smooth functioning of language. Also, this provides an apt moment to reflect on the 
final kind of chapter included within this book, which might be best described as a form of "academic biography".

There is a tone of generosity that runs through this text, and it is particularly revealed in those chapters that explore the academic histories of different intellectual encounters with Olsson (and others). Chapters by Reginald Golledge, Michael Dear and Trevor Barnes (which include an interview with Olsson conducted by Barnes in 2000) provide moving memories and reflections on their first academic encounters with Olsson, whether as students, doctoral researchers or colleagues. In Michael Watts' chapter "Of Bats, Birds and Mice" (pp. 143-154), for example, he recalls attending a presentation at which he first witnessed Olsson pacing before the audience "like a caged panther in a zoo" (p. 149). Watt's text, which centers upon the formative years that Olsson was based in Ann Arbor, Michigan (1966-1977), also provides a wonderful window into broader US intellectual contexts, as well as those often unspoken values and commitments that are bound up with the lives of academics.

At various stages in these academic biographies Olsson is discussed alongside or juxtaposed with another great Swedish geographer, Torsten Hägerstrand. The introduction by Abrahamsson and Gren also frames this pairing (p. 6), although its elaboration is suspended. Despite their important differences - in style, method or over the normative possibilities for spatial planning - there are no doubt secret passages of communication that flow between their respective bodies of work. In minimalist style, these passages could be summarized as follows: (i) a prioritization of Relations above any given thing, object or being; (ii) a foregrounding of time as open, existentially uncertain and irreversible; and (iii) a passion for problematizing geometry as a possible language of spatial form. As a reader interested in the histories and geographies of spatial thought, a more sustained interrogation of the consistency, for example, of Olsson and Hägerstrand, perhaps in relation to Swedish geography more broadly, would have been welcome (cf. Buttimer and Mels, 2006).

Many of the essays, both analytic and biographical, reflect on the singular style and world that Olsson conjures through his writings, noting how his work has at times been accused of excessive abstraction, obfuscation, arrogance, mysticism and elitism. However, as Martin Gren puts it in his introductory essay: “Olsson's inability to suppress his desires to speak and write from any other topos than his own ... should certainly not be mistaken for a solipsistic geography of private affairs." (p. 7). After all, one does not reprimand the Pink Panther for painting the world pink. For Deleuze and Guattari, the Pink Panther even represents a veritable ethical demand: "The Pink Panther imitates nothing, it reproduces nothing, it paints the world its color, pink on pink; this is its becoming-world" (Deleuze and Guattari, 2004:11). Also, one cannot but be struck, in re-reading Olsson's essays, by the use of images, diagrams and novel geometries through which his singular thought is painted. What Olsson exposes is the joy of - for want of a better phrase - diagrammatizing thought: that capacity to craft and sculpt concepts into minimalist spatial abstractions and images.

I want to finish this review by considering two more chapters: those by David Jansson and Chris Philo. Respectively, they explore the corpus of Olsson's work in terms of the discourses and practices of non-Western "mysticism" and in relation to debates over the status of "madness". Both chapters present useful articulations of Olsson in different kinds of context (therapeutic, pathological, transgressive, spiritual etc.). However, they can also be seen to offer a more straightforward or immediate response to the encounter with Olsson's work: is he mad? Is he a mystic?

There is a residual danger in such framing of Olsson in terms either of a logic or language of madness or as a similarly transgressive and heterogeneous figure such as that of the non-Western mystic or "rogue guru" (the latter being explored in Jansson's chapter "Crazy Wisdom and Recovering the Human in Olsson's Method of Critique", pp. 169-187). The danger is that it has the capacity to performatively place Olsson's writings and thought beyond serious geographic reflection - even when the objects of Olsson's interrogations are precisely the mundane, habituated and everyday spatial grammars of language or cartographic reason. Philo touches upon this problem in his chapter, "Gunnar Olsson, figures of 'Madness' and a Form of 'Schizologie"', in which he explores how Olsson's writings consistently reckon with the horror and madness bound up with the deconstruction of the foundations and norms of cartographic reason. For Philo, and as explored by Olsson in his magnum opus Abysmal, it is in such an anti-foundationalist context that particular devices of cartographic reason, such as the equal sign or Saussurean bar, provide comforting devices for "finding one's way" in the world. In Philo's words: “To avoid the 'horror', to avoid the madness, is hence to accept the 'blessing in disguise' of the 'equal sign', the sign that enables us to name, to designate, to fix what is in the world, what we can conventionally trust to remain stable, enduring and simply there all around us, repeatedly available to us in one way or another" (p. 304). Set against the broader context of Olsson's work, these cartographies of reason appear as "the kind of error without which a certain species of life could not live" (Nietzsche, 1968, Sect. 493).

Thinking in the "no-man's land" (Olsson, 1980:66) between poetry and science, or upon the intense, meditative possibilities of a "mandala" for human action - what Olsson offers may appear, as already noted, absorbed, maddening or self-spun. But it in fact has a minimalist and far more generous name: thinking. And perhaps the most significant or joyous element of Olsson's work is his affirmation that it is this - thinking - that should be taken as a properly humangeographical activity, that it is something to be practiced and valued because it is expressive and affirmative of our humanity. 


\section{References}

Buttimer, A. and Mels, T.: By Northern Lights: On the Making of Geography in Sweden, Ashgate, Aldershot, 2006.

Deleuze, G. and Guattari, F.: A Thousand Plateaus: Capitalism and Schizophrenia, Continuum, London, 2004.
Nietzsche, F.: The Will to Power, Vintage Books, New York, 1968. Olsson, G.: Birds in Egg/Eggs in Bird, Pion Ltd., London, 1980. 